Perspective

\title{
Buen Vivir: A Path to Reimagining Corporate Social Responsibility in Mexico after COVID-19
}

\author{
Bryan W. Husted
}

check for updates

Citation: Husted, B.W. Buen Vivir: A Path to Reimagining Corporate Social Responsibility in Mexico after COVID-19. Sustainability 2021, 13, 6451. https://doi.org/10.3390/ su13116451

Academic Editor: Mohammad Nurunnabi

Received: 9 April 2021

Accepted: 2 June 2021

Published: 6 June 2021

Publisher's Note: MDPI stays neutral with regard to jurisdictional claims in published maps and institutional affiliations.

Copyright: (C) 2021 by the author. Licensee MDPI, Basel, Switzerland. This article is an open access article distributed under the terms and conditions of the Creative Commons Attribution (CC BY) license (https:/ / creativecommons.org/licenses/by/ $4.0 /)$.
EGADE Business School, Tecnologico de Monterrey, Monterrey 64849, Mexico; bhusted@tec.mx

\begin{abstract}
The COVID-19 pandemic has exposed the unsustainable relations between business, society, and the natural environment in Mexico and around the world. Given these unsustainable relations, this essay asks the question: How can Mexican and multinational corporations enable human flourishing both at work and in the communities where they operate? It answers the question by examining how the Indigenous concept of Buen Vivir (living well) can serve as a basis for reimagining corporate social responsibility (CSR). Methodologically, it draws on ancient and contemporary Nahua poets as sources of ancestral Indigenous knowledge. Using these poets, the paper first establishes the applicability of Buen Vivir for Mexico. Relevant concepts include the quality of life, the relationship of humans to nature, the goal of economic growth, and the value of Indigenous knowledge. Using Buen Vivir as a framework for rethinking CSR, the paper integrates business within nature and dialogues with ancestral knowledge. It also focuses on localism and particularism, on quality in addition to quantity, on alternatives to economic growth, and on community. It ends by examining the implications of Buen Vivir for CSR theory and practice by incorporating Indigenous practices of communal work and conceptualizing the firm as a member of the community.
\end{abstract}

Keywords: corporate social responsibility; sustainability; Buen Vivir; Mexico; indigenous knowl-edge

\section{Introduction}

Monequi xihmalhui nochi tlen oncah ipan tlaltipactli. Ipampa tonana tlaltipactli tech tlacualtia, tech yolchicahua. Queman timiquih tech selia itlacayotipah.

You should honor all that exists on the earth. Because Mother Earth provides our food, strengthens our heart. We die, she receives us in her bowels.

Mother of Natalio Hernandez

Sometime toward the second half of 2019, near the city of Wuhan in China, a coronavirus crossed over from an animal population, possibly bats, to the human population [1,2]. Although the exact origin of the coronavirus is still uncertain, Wuhan itself is a fascinating city and provides the perfect setting for zoonosis - the transmission of diseases from animals to human beings. The city's population has almost doubled in the last 30 years, now reaching 11 million inhabitants. Wuhan's growth is a classic instance of rapid development, which has led to significant industrial pollution [3]. Yet the history of Wuhan conforms to a broader pattern of uncontrolled growth stressing ecosystems. As the city grows, deforestation expands, and animal-human contact occurs more frequently [2]. Stressed ecosystems are similar to stressed humans. When animals are stressed due to the encroachment of human populations disrupting their ordinary routines-animals react just like humans, their immune systems become depressed and are more susceptible to infection from viruses like the coronavirus [4-7]. This rampant growth has resulted in a surprisingly costly pandemic. The economic cost of the COVID-19 virus is estimated to reach \$16 trillion in the United States [8] and \$28 trillion around the world [9]. Yet despite the cost of COVID-19, World Health Organization Director-General Dr. Tedros Adhanom Ghebreyesus has warned that COVID-19 will not be the last pandemic, nor the most virulent one [10]. 
It is my position that COVID-19 provides a wake-up call to humans around the planet. Human interference with natural systems is increasing and is having significant consequences. COVID-19 requires that we pause to think carefully about our relationship with nature-before it is too late. However, it is not just a wake-up call in general, but a wake-up call to corporate social responsibility (CSR) scholarship and practice in particular. CSR is precisely that field of management that examines the nexus between the firm, society, and the natural environment, which is where the pandemics of the last 100 years have originated and will continue to emerge [11].

Yet the solutions cannot be of a one-size-fits-all approach [12]. Given the unique cultural, political, social, economic, and ecological conditions of each country and region, solutions must be worked out at a local level. In this paper, we examine the case of Mexico, which has and continues to neglect the natural environment despite CSR programs implemented by many firms [13]. In Mexico, conflicts between economic growth and nature are increasing and provoking human responses. Protests against wind farms in Oaxaca [14], blockades of trains by the Yaqui in Sonora [15], and opposition to a natural gas pipeline from Tuxpan to Tula [16] all exemplify conflicts where the human relationship to nature is at the core; these recent conflicts reflect an increasing rejection of the behavior of both national and multinational firms in Mexico. A common thread is the failure of companies to take into account local mores and customs.

In the case of the Tuxpan-Tula pipeline, TC Energy Corporation, parent of the TransCanada Pipelines, which was originally awarded the contract to build the pipeline, had a high reputation for CSR. The parent company scores in the upper $64 \%$ of over 17,760 firms for CSR [17] and was listed among the top 50 corporate citizens in Canada's Corporate Knights as recently as 2018 [18]. Although no longer on that list of socially responsible companies, even when it was on the list, the builder of the Tuxpan-Tula pipeline had been subjected to almost constant criticism and opposition by local communities directly affected. Now the project is being converted to a public-private partnership. What good has its CSR generated?

In this paper, I argue that the poverty of business-society and business-environment relationships in Mexico is due partly to the failure to develop autochthonous approaches to CSR that incorporate local knowledge about Mexico's cultures. So, the question I ask is: How can Mexican and multinational corporations enable human flourishing both at work and in the communities where they operate? Generally speaking, the literature on corporate social responsibility has been built on largely Western, European sources such as Aristotle and Immanuel Kant with occasional references to Eastern philosophy [19]. We extend the CSR literature to account for an authentic approach to social responsibility in Mexico by augmenting it with the insights of Buen Vivir, meaning "living well"-a philosophy of human flourishing and the good life with direct roots in the Indigenous cultures of Mexico and Latin America.

Drawing from Buen Vivir, as evidenced by Indigenous sources, both classical and contemporary, I argue that human flourishing in Mexico requires a reconceptualization of well-being and the quality of life, of human relations with nature, of development focused on economic growth, and a revalorization of Indigenous cultures and knowledges. This argument suggests that we should approach problems of human flourishing in a different way by building upon the age-tested values inherent in Buen Vivir.

As the Canadian philosopher Charles Taylor notes in his book A Secular Age: "Every person, and every society, lives with or by some conception (s) of what human flourishing is: what constitutes a fulfilled life? What makes life really worth living? What would we most admire people for? We can't help asking these or related questions in our lives. And our struggles to answer them define the view or views that we try to live by, or between which we hover. At another level, these views are codified, sometimes in philosophical theories, sometimes in moral codes, sometimes in religious practices and devotion. These and the various ill-formulated practices which people around us engage in constitute the resources that our society offers each one of us as we try to lead our lives" [20]. 
This paper seeks to begin to answer the question posed by Charles Taylor: what is the conception of human flourishing appropriate to the unique cultures of Mexico? We begin by describing the method used to answer this question and then examine the concept of CSR and suggest how it is fundamentally broken by not being developed autochthonously. We then look at the origin and evolution of the current conception of CSR in Mexico. After reviewing this evolution, we turn to Buen Vivir as a relevant source for reconfiguring Mexican CSR. We compare the worldviews of contemporary approaches to CSR with Buen Vivir and then reimagine a CSR based on Buen Vivir. Finally, we develop the implications of a Buen-Vivir-based CSR for current business-society issues.

\section{Method-Boundaries and Sources}

The approach of this paper is qualitative, based on a methodical hermeneutics [21]. We draw specifically from sources in the Nahua culture of Mexico. The Nahua people inhabit large regions of central Mexico, some of whom descended from the Aztecs, who ruled much of this area at the time of the Spanish conquest. Today, their language, Nahuatl, is spoken by over 1.5 million people and has one of the largest literatures of all Indigenous languages in the Americas. This literature includes not only pre-Columbian contributions, but also contemporary thinkers. We draw on this literature in order to access the ancestral knowledge of a Mexican Indigenous people to show its consistency with a larger body of Indigenous thought in Latin America referred to as Buen Vivir.

Indigenous communities have generally not been viewed as sources of valid knowledge production [22]. Unlike modern research traditions in the West, Nahuas consider nonpropositional knowledge to be key to solving problems for societal challenges [23], which is communicated through stories and poetry [23]. Consequently, this essay draws upon Indigenous, specifically Nahua, poets in Mexico. Poets are the main expositors who interpret and expound an environmental ethic rooted in their communities [24]. For many Nahua poets, there is a continuity between pre-Columbian times and contemporary elders [23]. Nahua thinking emphasizes two kinds of knowledge: knowing with the heart (affective intelligence) and knowledge with a face or knowledge based on personal experience [23]. We will draw on these two kinds of knowledge as expressed by Nahua poets.

The argumentation is essentially that Buen Vivir provides a way to articulate the meaning of the texts and therefore should be pursued as a way to understand these poets and the culture and worldview they represent [21]. Thus, reviewing these texts provides a way to reimagine CSR through the lens of Buen Vivir [25].

\section{CSR: International Origins and Evolution in Mexico}

Corporate social responsibility has been defined in a myriad of ways and there continues to be a lack of consensus regarding its meaning [26,27]. Keith Davis defined CSR as: "the firm's consideration of, and response to, issues beyond the narrow economic, technical, and legal requirements of the firm. It is the firm's obligation to evaluate in its decisionmaking process the effects of its decisions on the external social system in a manner that will accomplish social benefits along with the traditional economic gains which the firm seeks" [28]. McWilliams and Siegel define CSR in terms of: "actions that appear to further some social good, beyond the interests of the firm and that which is required by law" [29]. In both cases, social benefits go beyond the narrow economic benefits of the firm and the requirements of the law. Hence, at the heart of these CSR definitions is a corporate-centered, win-win approach to solving social and environmental problems in which CSR projects should benefit society and the environment without detriment to corporate profits. Yet there is no unifying theoretical framework that includes all of these many approaches [26].

The modern CSR concept can be dated to the 1950s with the publication of Howard Bowen's [30] Social Responsibilities of the Businessman. However, its antecedents go back at least to the medieval era and the miners' guilds of the Ruhr valley in Germany, which provided miners with mutual protection in case of accidents or sickness [31]. Later, German industrialists such as Alfred von Krupp [32] developed modern welfare capitalism in the 
mid-19th century by providing care of the infirm, old age pensions, housing, and consumer cooperatives for their employees. These early efforts were focused on issues of health and welfare but neglected the natural environment.

The modern CSR concept later subordinated these health and welfare considerations to a more general focus on philanthropy, eventually expanding to issues of strategic CSR and a vision of shared value in which social initiatives were to be designed with the intention of benefiting both the community and the firm $[33,34]$.

In some sense the history of CSR in Mexico loosely shadows its development elsewhere. As an important exception to foreign influence, some scholars point to pre-Hispanic antecedents in the practices of tequio by the Aztecs and other original peoples of the region, which placed responsibility for providing public goods on the community as a whole [34]. After the conquest of Mexico by the Spaniards, the Catholic church led efforts for social responsibility up to the mid-19th century, when liberal reforms by Benito Juarez, continued by Porfirio Diaz, opened up responsibility for social welfare to private organizations [35]. With the victory of the revolutionaries at the end of the Mexican Revolution (1910-1920), the government began to assume a greater social focus, which shifted from the church to the state [36]. Still, the business sector did not withdraw from their responsibility and the northern industrialists turned to the welfare capitalism of the United States as the inspiration for their own programs in the early 1900s [37]. Catholic social thought, as evidenced by the papal bull Rerum Novarum of Pope Leo XIII, also motivated Catholic business leaders to take care of their workers [35,36].

Modern CSR, dating from the 1950s in the United States, also diffused to Mexico [36]. This modern CSR had a more limited focus and initially emphasized corporate philanthropy. As the North American Free Trade Agreement came into force in 1994, many Mexican corporations abandoned welfare capitalism. Later, a more expansive agenda developed, as reflected in the United Nations' Global Compact and the Global Reporting Initiative (GRI) [35]. Major Mexican corporations followed suit, adopting the international CSR agenda, and many of them have now agreed to comply with the Global Compact and GRI [36].

\section{The Problem of CSR}

CSR has had a checkered history in its relationship with the natural environment and local communities. It is aligned with the concept of green growth and the possibility of a win-win for the company and the environment [12]. There has been hope that the sustainable development goals (SDGs) would help re-orient the CSR agenda toward sustainable development both nationally and internationally [38]. Montiel [39] argued that CSR and corporate sustainability are quite compatible, explaining that: "Both CSR [corporate social responsibility] and CS [corporate sustainability] aim to balance economic prosperity, social integrity, and environmental responsibility, regardless of whether they conceptualize environmental issues as a subset of social issues or as the third element of sustainability." Yet efforts to "green" business through CSR have been found to be largely ineffective [12].

In the case of local communities, CSR has been conceptualized in terms of the "social license to operate" so that companies need to obtain the moral approval of the community where they are located [40]. The social license to operate has been defined as "the acceptance or approval by local-if not Indigenous-communities and stakeholders of a business enterprise's operations or projects in a certain area" [40]. Where this social license does not exist, members of local communities have undertaken actions, such as obstructing railroad tracks as in the case of the Yaqui in Sinoloa [15] or opposing the construction of wind turbines by Zapotec peoples in the isthmus of Tehuantepec in Oaxaca [14], in order to protest actions taken by firms without their consent. Despite adopting CSR programs and engaging CSR consultants, these conflicts are common throughout Latin America as Indigenous groups come into conflict with large companies for the failure to obtain consent [41]. 
Consequently, contemporary CSR, as part of a global movement, seems to have exhausted its possibilities for enabling firms to interact with local communities and the environment in a meaningful way, especially in emerging market countries like Mexico, where the win-win is a win-win for companies and the local environment and community are forgotten, unless they appear on some company's CSR checklist. Hence the need for a more culturally consonant approach to CSR.

\section{Can Buen Vivir Provide a Solution?}

What is the solution? If corporate social responsibility is to serve human and social flourishing, "eudaimonic values are and should be fundamental to the ends served by private enterprise" [42]. Eudaimonic refers to "living a life of virtue in pursuit of human excellence." Such virtues are not foreign to Mexico as its ancient ethics includes such ethical norms and virtues as truthfulness, respect, humility, prudence, and reverence [43], all of which are related to human flourishing. Hence, there are important resources within Mexican culture for such an autochthonous approach, which is congruent with Buen Vivir, more broadly.

Although originally rooted in the concept of the Sumac Kwasay of the Quechua people of the Andes, Buen Vivir captures a range of ideas common to Indigenous peoples across Latin America. It is both post-capitalist and post-socialist in its critique of contemporary economic systems [44]. In Mexican languages, it is captured by such terms as "lekilaltik, tojolabal ('el bien nuestro' [our good]) y lekil kuxlejal, tzeltal y tzotzil ('la vida buena' [the good life]); nava ku ka'anu in ñú, mixteco ('Para engrandecer al pueblo' [to ennoble the people]); kualli sechantis, nahuatl ('Viviremos bien, nuestro hogar estará bien, sin problemas' [we will live well, our home will be fine, without problems]); pinantikua, purepecha ('Vida en silencio, armonia. Pasividad dentro de una comunidad' [life in silence, harmony]); susu chúnu, ssacru te juís chúnu, zapoteco ('Vivimos en calma, tranquilos, muy bonito' [we live in calm, tranquilly, very beautiful]); kjua nchán, mazateco ('Situación, problema o cuestión de paz' [situation, problem or matter of peace]); ch'ijcaj, chontal ('Tranquilidad y armonia' [tranquility and harmony]); jo mubu, mazahua ('Gente de buen corazon' [good-hearted people]); etsáán olal, maya ('Quietud, sosiego, paz, consuelo y tranquilidad' [stillness, calm, peace, comfort and tranquility])." [45]. Therefore, Buen Vivir is an intercultural position that knits together ideas of Indigenous origin as well as critiques of modernity [44].

Although Buen Vivir does not constitute a unified philosophy, it does share four main points [46] regarding: (1) wellbeing and the quality of life; (2) the relationship of human beings to nature; (3) models of development with the objective of economic growth, and (4) the value of Indigenous cultures and knowledge. Let us look at each of these points-one by one. In so doing, I will demonstrate how Buen Vivir resonates with elements of Nahua culture in order to show that Buen Vivir does apply beyond its Quechuan origins and can serve as a platform for organizing some Indigenous Mexican thought as well.

First, Buen Vivir reconceptualizes well-being by going beyond economic welfare. It values harmony, equity, community, subjectivity, and spirituality. For the Nahua, there can be no single understanding or approach to environmental ethics, given that it is rooted in specific places and experiences [24]. Yet within this diversity, there is a unity in the world, captured by the metaphor of music. Yolanda Matías García writes:

Come and sing to the harmony of the world,

So that hearts beat with joy,

Colorful landscapes light up

And let there be no sadness in humanity [47].

Music evokes the unity in diversity that creates a harmony, to which human hearts beat. For the Nahua, these songs are combined with flowers to create flowered songs, which is a metaphor for poetry-and the embodiment of knowledge.

One of the most important flowers in Nahua understanding is maize or corn, which represents the interconnection of humans and nature. Maize is the source of both physical 
well-being through the sustenance it provides as well as communal well-being and happiness through the relations that it engenders [23]. In the voice of maize itself, Matías García writes:

I am the happiness of man

Because I am his food

The earth, the sun and the water

They give me life and love [47]

Here Matías García places maize at the center of a system that unites earth, sun, water, and people. In both selections of verses, human happiness does not deal with winning some sort of competition, but rather being in harmony with the elements of the natural world.

Second, rather than viewing people at the center of the natural world, Buen Vivir conceptualizes human beings as part of nature. It goes beyond most conceptualizations of sustainability, which ultimately justify pro-environmental action in terms of its impact on future generations of humans. Instead, referring back to the verses by Yolanda Matías García about maize, it is maize, not people, that stands at the center of the system that connects human beings to the sun, earth, and water.

The centrality of nature can be sensed in the Cuicapeuhcayotl, which means "the beginning or origin of songs." This manuscript is the first in an anonymous collection of Nahua songs from the 16th century known as Cantares Mexicanos ("Mexican Songs") and provides an idea of the intrinsic value of nature and the need to do it no harm.

"Truly as I walk along I hear the rocks as they were replying to the sweet songs of the flowers; truly the glittering, chattering water answers, the bird-green fountain, there it sings, it dashes forth, it sings again; the mocking bird answers; perhaps the coyol bird answers and many sweet singing birds scatter their songs around like music. They bless the earth pouring out their sweet voices. I said, I cried aloud, may I not cause you pain ye beloved ones, who are seated to listen; may the brilliant humming-birds come soon" [48].

Causing no pain is related to the idea that human welfare depends on all nature. As poet Natalio Hernández writes: "The future of humanity depends on the future of the earth. Indigenous peoples keep this consciousness alive, they never renounced it. For them, the earth is Tonantzin, our Mother" [49]. In both the Cuicapeuhcayotl and Hernandez, we see a very different conception of nature-human beings are part of nature and the Earth is properly considered our mother, not a resource for humanity.

Third, Buen Vivir critiques linear models of development, which have an almost exclusive focus on achieving economic growth. In a series of laments addressed to Mother Earth, Natalio Hernández speaks directly to this issue in these words:

This sadness

This worry

Comes with extraction

From the "chapopote," oil,

That they have begun to extract,

Large companies.

With this job

They have started to pollute the water,

The air, the cultivated land;

And the trees start to get sick

When the birds migrate, when the animals flee.

Little by little, everything will disappear,

Everything will deteriorate... [49]

In these verses, Hernández criticizes the "large companies" for their role in oil drilling and degrading the environment. The warning could not be more ominous: everything will disappear. 
Fourth, Buen Vivir respects the value of Indigenous cultures and ancestral knowledge ("saberes") and is thus related to current discussions related to decolonization and interculturality [22]. Again, Natalio Hernández vindicates traditional knowledge with these words:

We no longer wish that

Our children live with tears

We no longer want

Them to pass through the world as orphans,

Because they have ancient roots,

Because they have their own face,

Because they have ancient wisdom

That has been increasing

With other wisdoms

Which have reached the Huastecan land;

That is why my song is due;

My song of joy,

Mother Earth,

Huastecan land [50].

The reference to Indigenous people as children who live as orphans, suggests the sense in which they are often cut off from their roots-the ancestral knowledge or ancient wisdom-taught both in pre-colonial times and currently by their elders [23].

In this next selection, we read about how the knowledge of the ancestors guides us today:

Mother Earth,

Huastecan land,

Where it has its dwelling

The ancient of days, hehapatl tetahtszin,

Our grandfather fire, tocoltzin tlixahuantzin,

The old man who strengthens us

In times of winter,

That illuminates us

In times of gloom,

That gives us strength

When we get sick;

The old man who saves

The memory of generations

In the passing of years,

In the passing of days

And of the moonlit nights;

$\mathrm{He}$, the ancient fire,

Renews the word,

When we light the fire;

Renew its life

And then it blooms

Speaks, dialogues 
With us,

Protects us

It strengthens us,

It guides us [50].

In this comparison of wisdom to an ancestor, Hernandez explains how this wisdom guides current generations in sickness and in life. This knowledge protects and strengthens those who dialogue with it and so current generations should not feel orphaned in this world.

Through this mélange of poems both ancient and contemporary, we obtain a sense of the way that Buen Vivir, though Quechuan in origin, represents the thought of other Indigenous groups in the Americas, such as the Nahua in Mexico, thus providing a framework for contrasting the worldview of current conceptualizations of CSR with Buen Vivir.

\section{Comparing the Current Worldview of CSR to Buen Vivir}

Given the vastly different approaches encompassed by CSR [26], it would be impossible to compare them all to Buen Vivir within the confines of this paper. Instead, I take a meta-theoretical approach by comparing the basic assumptions upon which CSR and Buen Vivir are based [51]. In Table 1, adapted from Maldonado Rivera, Reyes Velásquez, and del Valle Rojas [52], I compare the contemporary Western worldview upon which CSR is based and the worldview of Buen Vivir.

Table 1. Contrasting worldviews.

\begin{tabular}{|c|c|}
\hline Modern Euro-Centric Worldview & Worldview of Buen Vivir \\
\hline Instrumentalization of nature & $\begin{array}{c}\text { Human integration with and from the perspective } \\
\text { of nature }\end{array}$ \\
\hline Fragmentation of knowledge, esthetics, and norms & Dialogue of ancestral knowledge \\
\hline Universalism & Particularism \\
\hline Quantification & Quality \\
\hline Interventionism and development & Criticism of development \\
\hline Individual & Community \\
\hline
\end{tabular}

Translated and reproduced with permission from Claudio Andrés Maldonado Rivera, Carlos Reyes Velásquez, and Carlos del Valle Rojas, Chasqui: Revista Latinoamericana de Comunicación; published by CIESPAL, 2021.

Starting with this Table, we can begin to analyze the similarities and differences between contemporary CSR and Buen Vivir. In terms of the instrumentalization of nature, much of CSR research has focused on the business case, which is the argument that companies should invest in CSR as long as it generates positive economic returns for business [29]. The business case has consumed the attention of CSR researchers over the years $[53,54]$, but has not led to serious questioning about whether CSR investment has produced positive impacts for the environment and society [55]. This instrumentalization of nature, including humankind, stands in stark contrast to Buen Vivir, which sees nature as having intrinsic value on par with human beings. Rather than the optimization framework that pervades CSR and sustainability [56], Buen Vivir places priority on nature so that it cannot be seen as an instrument, but as an end in itself.

With respect to knowledge, Western science has become increasingly fragmented at least since the 18th and 19th centuries when the social sciences began to diverge from moral philosophy, culminating in their current separation into disciplines as diverse as economics, sociology, political science, and psychology, among others [57]. We see this fragmentation not only in CSR research, with research streams flowing from economics [58], psychology [59], and sociology [60], resulting in a multiplication of academic brands such as creating shared value [61] and conscious capitalism [62], but also in the inherently interdisciplinary field of management.

In contrast, Buen Vivir gives weight to ancestral knowledge, passed on from generation to generation. It is locally rooted in a specific community and geography, which represent the distillation of years of experience within that community and geography [22]. Rarely 
has science given weight to Indigenous knowledge and, on the contrary, such knowledge has been viewed as anti-scientific [22]. For example, in the case of Canadian fisheries, there was a divergence in Indigenous knowledge and Western knowledge related to water quality in the Saskatchewan River delta. Whereas Western science indicated that the water was "safe" for human consumption; Indigenous ancestral knowledge declared the water to be of poor quality [63]. Based on Buen Vivir, a corporate water-quality standard would take ancestral knowledge seriously and require that corporate environmental management adopt the stricter, Indigenous standard.

CSR as an extension of a Western world view has largely been universalistic [64]. CSR programs are often based on global social and environmental issues, such as the UN's Sustainable Development Goals. There is some discussion of translating and adapting CSR programs by MNEs to local contexts [65], but little discussion of developing bottom-up autochthonous CSR programs. Buen Vivir views knowledge as localized and particularized in light of a complexity that is very difficult to reduce to general laws [66].

Regarding the different foci on quantification vs. quality, CSR as currently practiced is highly focused on ratings and quantitative evaluations, whether speaking of KLD-MSCI, Sustainalytics, Asset4, B Impact Assessment, Arabesque, SDGs, GRI, IRIS, or IMP [67,68]. These systems involve indicators and checklists in order to determine the "social performance" of firms. Yet these systems rarely focus on impacts on the environment or the community itself, which often require more detailed, qualitative approaches to research and return to "small data", which would be consistent with Buen Vivir [55].

CSR is built on the growth model of development and is consistent with current notions of sustainable development, which promote green growth [39]. In contrast, Buen Vivir critiques most models of economic development and the idea of growth itself [44]. Green growth becomes an oxymoron as demonstrated by recent research that suggests that the win-win of environmental quality and economic prosperity we hope for is not easily achieved in practice [69]. Buen Vivir is consonant with more transformative visions of green economy, such as "Green Revolution," which prioritize natural limits and human rights [12].

Finally, CSR and the Western worldview is essentially individualistic, permitting the concentration of wealth in the hands of a few [66] in a "winner takes all" society and requiring the poorest to pull themselves out of poverty by their own bootstraps. When firms engage in CSR, much of it reinforces elite causes and privilege and may increase inequality $[70,71]$. Buen Vivir shifts the focus from the individual to the community, empowering the whole community, especially the marginalized [72].

\section{Reimagining a CSR Based on Buen Vivir}

Given the current approach to CSR, what might a CSR based on Buen Vivir look like? In order to re-establish CSR on the foundation of Buen Vivir, we return to Table 1 to guide the discussion. After applying the six elements of Buen Vivir to CSR, we then engage in a thought experiment to see what this reimagined CSR would look like in practice.

First, it would take nature seriously and the role of people as part of nature. Nature cannot be manipulated to achieve the ends of business, but business must serve the flourishing of nature as well as human flourishing. CSR should be centered on human and natural flourishing, and not on business profits. The well-known business case for CSR would be flipped around into the CSR case for business, that is, business would be justified as an instrument to achieve the social and environmental goals encapsulated in CSR.

CSR would take ancestral knowledge seriously. As Nahuatl poet, Natalio Hernández explains: "Remember that the new generations are always nourished by old and deep roots. Old as I am, I still live, I live with strength and joy" [49]. One test for CSR would require asking: Is it consistent with ancestral knowledge? Where CSR is not consistent with ancestral knowledge, a red flag would go up, requiring deeper thought to understand why not, and how ancestral knowledge and CSR could become compatible. In this way, ancestral knowledge and Western science would co-construct "an inquiry-based approach to solving 
complex societal problems" [73]. Ancestral knowledge does not replace "other wisdoms," but complements and enriches it. Based on Mi'kmaq principles, the concept of "two-eyed seeing" compares the relationship between Indigenous knowledge and Western knowledge to two eyes. Each captures phenomena through a different angle, but together they create a more complete picture of reality [74]. In this way, neither way of knowing is meant to supplant the other, but to complement and respect each other. As Colbourne et al. [74] explain: "It is a practice of decolonizing research that stresses a weaving back and forth between separate but parallel ways of knowing (knowledge systems) each of which is important and necessary to generating knowledge and knowing that leads to greater socio-economic well-being in the world."

CSR would be based on particularistic and localized knowledge with solutions to social and environmental problems being developed to specific situations. For the Nahua, this experiential knowledge is expressed through the concept of ixtlamatilistli. Literally it means "face knowledge," and focuses on what can be known through the experience of the person - the face. Similar to breakthroughs related to personalized medicine, CSR would be localized as each community's unique culture, geography, and institutional profile would make it more or less susceptible to very specific problems.

Quality as opposed to quantity in CSR would require moving to "small data" focusing on the unique characteristics of each initiative and of each community where an initiative operates [55]. As in the case of two-eyed seeing, such a refocusing does not mean an abandonment of quantitative measurement or research, but a focus on projects and programs in concrete settings rooted in the researcher's experience.

CSR would fundamentally move from a focus on sustaining economic growth to one of ecosystem wellbeing, which includes human beings along with other living creatures. As an important consequence of Buen Vivir, de-growth would likely find its way into the heart of CSR [44]. It includes a vision where society uses fewer natural resources by living more simply [72]. The focus on sufficiency—on what is enough for well-being-belies the current logic of economic maximization [75].

CSR based on Buen Vivir would be developed in and within communities-not around communities, which the company too often views as another group of stakeholders [76]. In other words, the company would see itself as part of the community and look at the community as part of itself. The welfare of the community and the welfare of the company would be inextricably interwoven. The current distancing of consumption and production decisions, which leads to externalities, would be reduced [77].

A useful thought experiment is to conceptualize how this reimagined CSR could be applied to a concrete issue in practice. The difference between CSR based on a Western worldview and a worldview based on Buen Vivir can be seen in the case of wind energy investment in Isthmus of Tehuantepec in Oaxaca [14]. Wind energy is viewed by Western companies as an excellent way to comply with the Sustainable Development Goals, specifically as it relates to the use of sustainable energy. These are clearly laudable objectives from the perspective of CSR [78,79]. However, from the perspective of Indigenous peoples and their culture, values, and ancestral knowledge, the land is not a thing, but a living being with a spiritual essence. Therefore, although sustainable development, based on Western knowledge, has great merit, it can conflict with Indigenous values, culture, and knowledge $[14,80]$. CSR based on Buen Vivir would take ancestral knowledge seriously and would acknowledge the spiritual element of the land. The company would proceed with sustainable development projects as members of the community together with Indigenous people who have lived in the Isthmus for centuries.

The governance of these relationships is critical. Unlike ordinary stakeholder relationships, Buen Vivir would require that the local Zapotec and Ikoojts people not just be consulted as stakeholders, but the company would need to see itself as a member of the community and constitute a community advisory board to integrate ancestral knowledge with Western knowledge [63]. Such an advisory board would take into account the particularistic, place-based, and qualitative understandings of the damage that can be caused by 
wind energy plants. It would make decisions, even in the absence of scientific evidence and Western approaches to cost-benefit analysis [80]. The company would have to yield to the decisions of such a community advisory board [63].

\section{Implications}

What are the practical and theoretical implications of CSR based on Buen Vivir? I argue that Buen Vivir has important implications for the practice of community social initiatives, concepts of corporate citizenships, stakeholder management, consent, and current conceptions of the triple bottom line. Let us look at each of these points in turn.

One Indigenous practice that reflects Buen Vivir and which could make its way into CSR is tequio. Although its origins are ancient, tequio is a term still used by the Ayuuk in Oaxaca. In fact, its practice is found among Indigenous peoples throughout Latin America [81]. It refers to the work that members of an Indigenous community must undertake in order to provide public goods for the community and is an ancient form of social responsibility in Mexico [34]. Colín explains tequio in this way: "Emerging from the word tequitl, or work, tequio is the ancient concept that every person has a civic duty, an obligation to contribute to the vitality of the calpulli [neighborhood] as directed by the leaders of the community. In ancient Anáhuac [Mexico], every citizen of a calpulli was obliged to contribute to agriculture and greater public works. Labor on these projects (e.g., executing large ceremonies, building housing and roads, hosting visiting dignitaries) [was] rotated among citizens" [82].

Tequio refocuses the sense of CSR, which has also been defined as "the private provision of public goods" [83] to the community provision of public goods. Tequio is the foundation for community-based enterprise, which provides a model for sustainable local development in poor communities [84]. Such a focus would find good support in the work of Elinor Ostrom and her colleagues, where she found numerous examples of local communities resolving ecological problems through localized, community-based solutions [85].

Such community provision of public goods through tequio is not just a dry concept, but a source of joy, as expressed by contemporary Nahua poet, Natalio Hernandez, who describes the emotion he felt about communal work:

I remember how I participated in mutual aid

Along with other young people from the town;

In one day we cleaned a cornfield

With much excitement we sowed

With great happiness we shared

The food of the crops [49].

What would the practice of tequio by companies look like? First, the company would be a member of the community with neither more nor fewer rights than that of any other member of the community. Second, the community would decide what projects to undertake, not the individual members or the company. Third, the company's employees would work shoulder to shoulder with all other community members in the development of public works or public goods. It would be a very different looking creature from current CSR initiatives, where the company decides what is best for the community and develops CSR initiatives in terms of what is best for its own interests.

Buen Vivir also has implications for the conceptual development of CSR, which is often conceived of as corporate citizenship [86]. Citizenship as a concept derives from ancient Greece city-states where citizens were members of these city-states with rights and duties. Modern, Western ideas of citizenship attach these rights and duties to political communities, usually nation-states [87]. What would it mean if CSR were to be seen as membership in local communities, which might be based on geography, culture, and language? A very different narrative about the relationship of companies to communities would arise through a CSR based on Buen Vivir. Instead of engaging in across-the-board CSR initiatives, any such community-based initiatives would be unique and developed according to the 
contours and needs of specific communities and geographies [88]. A community-based focus born of Buen Vivir would exclude the typical one-size-fits-all approach of modern CSR programs and be replaced by a sensitivity to the needs of specific communities [88]. CSR programs could not be standardized across facilities, but would need to take into account the unique features and contours of each community [12].

Hence, Buen Vivir implies a shift from stakeholder management to community engagement $[76,89]$. The stakeholder management approach essentially places the firm at the center and stakeholders in relation to the firm as they affect the firm's interests or the firm affects their interests (Freeman, 1984). Nevertheless, Buen Vivir suggests that firms should consider themselves as members of the community - with neither fewer nor greater rights than other members of the community.

CSR based on Buen Vivir would also incorporate the concept of free, prior, informed consent. Too often, CSR in relation to Indigenous communities has incorporated consultation of local communities but has not viewed the local community as having rights in and of themselves to give consent to CSR projects [41]. At least as practiced in Mexico, consultation has not been sufficient, but must require nothing less than consent [90]. While CSR at its best has incorporated two-way stakeholder dialogue, such approaches still privilege the firm as the leader of such exercises [89]. Buen Vivir does not privilege any member of the community and requires the concept of free, prior, informed consent in which Indigenous communities have demanded their rights in relation to corporate operations in the community, such that the community holds a fundamental right of veto unless the community as a whole benefits [91]. This represents a very different approach from the firm-centric stakeholder approach, where "stakeholder status connotes a right to give input in a deliberative decision-making process; it reflects neither decisional autonomy nor control over the terms of and procedures accompanying participation" [92]. Free, informed prior consent demands much more than a right to give input-in fact, it is the opposite, and requires decisional autonomy and control over the terms of and procedures of participation.

A final implication of Buen Vivir for CSR and sustainability is the incorporation of a fourth pillar or bottom line in the sustainability tripod so that it would focus on people, profit, planet [93], and culture [90]. A perusal of the Sustainable Development Goals reveals little reference to cultural aspects of sustainability such as linguistic diversity and local ecological knowledge [94]. A Buen Vivir focus would see culture, language, and ancestral knowledge as key to sustainability and therefore of corporate social responsibility. This focus does not refer to culture as a consumption activity, but culture as lived and produced by people. Buen Vivir would add an additional SDG, which would deal with preserving our biocultural heritage, including cultural and linguistic diversity and local environmental knowledge [94].

\section{Conclusions}

The case against current conceptualizations of CSR is strong. Lacking tangible social and environmental results, few public goods seem to have been provided privately through companies. The global CSR movement, as embodied by global frameworks such as the Global Compact and Global Reporting Initiative, have diffused around the world, with little evidence of substantive impact, being adopted mostly in symbolic ways [95,96]. Still, the most glaring indictment of CSR is the coronavirus pandemic, which has exposed the unsustainable development that has been the focus of current conceptualizations of CSR. Beyond a few recommendations to wash hands frequently and use face masks, the pandemic caught most companies and their CSR programs entirely unprepared. The pandemic calls for a careful rethinking of CSR and its firm-centric conceptualization of the relationship between the firm, society, and nature.

Such has also been the case in Mexico. In this paper, I have argued that it is time to rethink CSR and rebuild it from its roots by using local concepts and experiences. I believe that Mexico is well prepared to undertake this task given the wealth of resources it has 
within its Indigenous cultures. Whether from the Cantares Mexicanos of the 16th century or contemporary poets, an Indigenous ethic of value creation and trade does exist and can be applied today. Furthermore, I have shown that this ethic and philosophy is well summarized within the Indigenous-based concept of Buen Vivir, which permits a pan-Latin American approach. The problems of business in its relationship to society are clear. It is time to find solutions. Given that the solutions offered by imported versions of CSR have been found to be lacking, it is time to do the hard work of developing solutions based on the historical, philosophical, and literary resources of Mexico to heal the damage business has done and continues to do to Totlalnantsin-our mother Earth.

Funding: This research received no external funding.

Institutional Review Board Statement: Not applicable.

Informed Consent Statement: Not applicable.

Data Availability Statement: Data sharing not applicable.

Acknowledgments: The author gratefully acknowledges the guidance of Victoriano (Teposteko) de la Cruz Cruz who introduced him to Buen Vivir as a source for CSR. In addition, the author engaged in helpful conversations with Jason Good about the concept as it relates to ancient Nahua ethics. These acknowledgements do not imply any endorsement on the part of these individuals. The author is solely responsible for the content of the article and for any errors therein.

Conflicts of Interest: The author declares no conflict of interest.

\section{References}

1. Cyranoski, D. Profile of a killer: The complex biology powering the coronavirus pandemic. Nature 2020, 581, 22-26. [CrossRef]

2. McMahon, J. How Deforestation Drives The Emergence Of Novel Coronaviruses. Forbes, 21 March 2020 ; p. 5.

3. Chen, X.; Liu, X.; Hu, D. Assessment of sustainable development: A case study of Wuhan as a pilot city in China. Ecol. Indic. 2015, 50, 206-214. [CrossRef]

4. Borges, T.; Branford, S. Rapid deforestation of Brazilian Amazon could bring next pandemic: Experts. Mongabay, 15 April 2020.

5. Cheng, V.C.C.; Lau, S.K.P.; Woo, P.C.Y.; Yuen, K.Y. Severe Acute Respiratory Syndrome Coronavirus as an Agent of Emerging and Reemerging Infection. Clin. Microbiol. Rev. 2007, 20, 660-694. [CrossRef]

6. Daszak, P. Emerging Infectious Diseases of Wildlife-Threats to Biodiversity and Human Health. Science 2000, $287,443-449$. [CrossRef] [PubMed]

7. Jones, K.; Patel, N.G.; Levy, M.; Storeygard, A.; Balk, D.; Gittleman, J.L.; Daszak, P. Global trends in emerging infectious diseases. Nature 2008, 451, 990-993. [CrossRef]

8. Cutler, D.M.; Summers, L.H. The COVID-19 Pandemic and the \$16 Trillion Virus. J. Am. Med. Assoc. 2020, 324, 1495-1496. [CrossRef]

9. Gopinath, G. A Long, Uneven and Uncertain Ascent. Available online: https://blogs.imf.org/2020/10/13/a-long-uneven-anduncertain-ascent/ (accessed on 5 June 2021).

10. WHO. International Day for Epidemic Preparedness: WHO Director-General Dr Tedros Adhanom Ghebreyesus; World Health Organization: Geneva, Switzerland, 2020.

11. Honigsbaum, M. The Pandemic Century: One Hundred Years of Panic, Hysteria and Hubris; Hurst \& Co.: London, UK, 2019.

12. Healy, H. Conceptualising Green Economies: Origins, Evolution and Imperatives. In Decent Work and Economic Growth; Leal Filho, W., Azul, A.M., Brandli, L., Özuyar, P.G., Wall, T., Eds.; Encyclopedia of the UN Sustainable Development Goals; Springer International Publishing: Cham, Switzerland, 2019; pp. 1-15. ISBN 978-3-319-71058-7.

13. Barkin, D. The Social and Environmental Impacts of the Corporate Responsibility Movement in Mexico since NAFTA. N. C. J. Int. Law Commer. Regul. 2005, 30, 895-928.

14. Ramirez, J. Contentious Dynamics within the Social Turbulence of Environmental (In)justice Surrounding Wind Energy Farms in Oaxaca, Mexico. J. Bus. Ethics 2021, 169, 387-404. [CrossRef]

15. Mexico News Daily. Yaqui Train Blockade in Sonora Holds up Delivery of 1000 Containers. Available online: https:// mexiconewsdaily.com/news/yaqui-train-blockade-in-sonora-holds-up-delivery-of-1000-containers/ (accessed on 5 June 2021).

16. Bnamericas Oposición Indígena Mantiene Paralizados Gasoductos en México. Available online: https://www.bnamericas.com/ es/noticias/oposicion-indigena-mantiene-paralizados-gasoductos-en-mexico (accessed on 5 June 2021).

17. CSR Hub TC Energy Corporation CSR/ESG Ranking. Available online: https://www.csrhub.com/CSR_and_sustainability_ information/TC-Energy-Corporation (accessed on 28 December 2020).

18. Corporate Knights. 2018 Best 50 Results; Corporate Knights: Toronto, ON, Canada, 2018.

19. Sison, A.J.G.; Ferrero, I.; Redín, D.M. Some Virtue Ethics Implications from Aristotelian and Confucian Perspectives on Family and Business. J. Bus. Ethics 2020, 165, 241-254. [CrossRef] 
20. Taylor, C. A Secular Age; Belknap Press: Cambridge, MA, USA, 2007.

21. Rennie, D.L. Qualitative research as methodical hermeneutics. Psychol. Methods 2012, 17, 385-398. [CrossRef]

22. Smith, L.T. Decolonizing Methodologies: Research and Indigenous Peoples; University of Otago Press: Dunedin, New Zealand, 1999; ISBN 10:1 87713367 1.

23. Coon, A. Iajki Estados Onidos/She Went to the U.S.: Nahua Identities in Migration within Contemporary Nahua Literature, 1985-2014; University of Texas: Austin, TX, USA, 2015.

24. Lowman, S. Ecología Politica y Activismo Cultural en la Literatura Nahua de México [1985-2013]; University of Georgia: Athens, GA, USA, 2017.

25. McCaffrey, G.; Raffin-Bouchal, S.; Moules, N.J. Hermeneutics as Research Approach: A Reappraisal. Int. J. Qual. Methods 2012, 11, 214-229. [CrossRef]

26. Garriga, E.; Melé, D. Corporate social responsibility theories: Mapping the territory. J. Bus. Ethics 2004, 53, 51-71. [CrossRef]

27. Scherer, A.G.; Palazzo, G. The New Political Role of Business in a Globalized World: A Review of a New Perspective on CSR and Its Implications for the Firm, Governance, and Democracy: Political Role of Business in a Globalized World. J. Manag. Stud. 2011, 48, 899-931. [CrossRef]

28. Davis, K. The Case for and against Business Assumption of Social Responsibilities. Acad. Manag. J. 1973, 16, 312-322.

29. McWilliams, A.; Siegel, D. Corporate Social Responsibility: A Theory of the Firm Perspective. Acad. Manag. Rev. 2001, 26, 117-127. [CrossRef]

30. Bowen, H.R. Social Responsibilities of the Businessman; Federal Council of the Churches of Christ in America: New York, NY, USA, 1953.

31. Hielscher, S.; Husted, B.W. Proto-CSR before the Industrial Revolution: Institutional Experimentation by Medieval Miners' Guilds. J. Bus. Ethics 2020, 166, 253-269. [CrossRef]

32. McCreary, E.C. Social Welfare and Business: The Krupp Welfare Program, 1860-1914. Bus. Hist. Rev. 1968, 42, 24-49. [CrossRef]

33. Frederick, W.C. Commentary: Corporate Social Responsibility: Deep Roots, Flourishing Growth, Promising Future. Front. Psychol. 2016, 7, 129. [CrossRef]

34. Pérez-Morales, J.R.; Aldape-Alamillo, A.; Reyes-Martínez, R.M.; Hijar-Rivera, H.; Castillo-Pérez, V.H. History of Social Responsibility in Mexico: A Review of the Literature. In Advances in Human Factors, Business Management and Leadership; Kantola, J.I. Barath, T., Nazir, S., Eds.; Advances in Intelligent Systems and Computing; Springer International Publishing: Cham, Switzerland, 2018; Volume 594, pp. 183-190. ISBN 978-3-319-60371-1.

35. Blasco, M.; Zølner, M. Corporate Social Responsibility in Mexico and France: Exploring the Role of Normative Institutions. Bus. Soc. 2010, 49, 216-251. [CrossRef]

36. Cabrera Rubio, A.L. La Responsabilidad Social Empresarial de grandes multinacionales estadounidenses en México y su adaptación local desde la perspectiva institucional. Rev. El Col. San Luis 2016, 6, 116-158. [CrossRef]

37. Snodgrass, M.D. The Birth and Consequences of Industrial Paternalism in Monterrey, Mexico, 1890-1940. Int. Labor Work.-Cl. Hist. 1998, 53, 115-136.

38. ElAlfy, A.; Palaschuk, N.; El-Bassiouny, D.; Wilson, J.; Weber, O. Scoping the Evolution of Corporate Social Responsibility (CSR) Research in the Sustainable Development Goals (SDGs) Era. Sustainability 2020, 12, 5544. [CrossRef]

39. Montiel, I. Corporate Social Responsibility and Corporate Sustainability: Separate Pasts, Common Futures. Organ. Environ. 2008, 21, 245-269. [CrossRef]

40. Demuijnck, G.; Fasterling, B. The Social License to Operate. J. Bus. Ethics 2016, 136, 675-685. [CrossRef]

41. Fitz-Henry, E. Indigenous Peoples and Neo-Extractivism in Latin America. In The Palgrave Encyclopedia of Imperialism and AntiImperialism; Ness, I., Cope, Z., Eds.; Springer International Publishing: Cham, Switzerland, 2020; pp. 1-8. ISBN 978-3-319-91206-6.

42. Weisband, E. The Virtues of Virtue: Social Capital, Network Governance, and Corporate Social Responsibility. Am. Behav. Sci. 2009, 52, 905-918. [CrossRef]

43. Good, J.; Montes, P.V.; Husted, B.W.; de Mariscal, B.L. From Manhattan to Tenochtitlán: Identifying ethical commercial norms. J. Manag. Hist. 2018, 24, 435-456. [CrossRef]

44. Gudynas, E. Value, Growth, Development: South American Lessons for a New Ecopolitics. Capital. Nat. Social. 2019, 30, $234-243$. [CrossRef]

45. Concheiro Borquez, L.; Nuñez, V. El 'Buen Vivir' en México Fundamento para una perspectiva revolucionaria. In Buena Vida, Buen Vivir: Imaginarios Alternativos Para el Bien Común de la Humanidad; Universidad Nacional Autónoma de México: Mexico City, Mexico, 2014; ISBN 978-607-02-5400-0.

46. Villalba-Eguiluz, C.U.; Etxano, I. Buen Vivir vs Development (II): The Limits of (Neo-)Extractivism. Ecol. Econ. $2017,138,1-11$. [CrossRef]

47. Matías García, Y. Tonalxochimej: Flores del Sol; El Colegio de Guerrero, A.C.: Chilpancingo, Mexico, 2013; ISBN 978-607-7679-57-8.

48. Brinton, D.G. Ancient Nahuatl Poetry; Forgotten Books: London, UK, 2015.

49. Hernández, N. Yancuic Anahuac Cuicatl: Canto Nuevo de Anáhuac; Escritores en Lenguas Indígenas, A.C.: Mexico City, Mexico, 2007.

50. Hernández, N. Tamoanchan: La Tierra Originaria; Universidad de Guadalajara: Guadalajara, Jalisco, 2017.

51. Allana, S.; Clark, A. Applying Meta-Theory to Qualitative and Mixed-Methods Research: A Discussion of Critical Realism and Heart Failure Disease Management Interventions Research. Int. J. Qual. Methods 2018, 17. [CrossRef] 
52. Maldonado Rivera, C.A.; Reyes Velásquez, C.; del Valle Rojas, C. Emergência indígena, Comunicação-outra e Bem Viver. Pensar a pratica comunicativa dos povos indígenas. Chasqui Rev. Latinoam. Comun. 2015, 128, 165-182.

53. Lu, W.; Chau, K.; Wang, H.; Pan, W. A decade's debate on the nexus between corporate social and corporate financial performance: A critical review of empirical studies 2002-2011. J. Clean. Prod. 2014, 79, 195-206. [CrossRef]

54. Orlitzky, M.; Schmidt, F.L.; Rynes, S.L. Corporate Social and Financial Performance: A Meta-Analysis. Organ. Stud. 2003, 24, 403-441. [CrossRef]

55. Barnett, M.L.; Henriques, I.; Husted, B.W. Beyond Good Intentions: Designing CSR Initiatives for Greater Social Impact. J. Manag. 2020, 46, 937-964. [CrossRef]

56. Cashore, B.; Bernstein, S. Bringing the Environment Back In. Available online: https://www.researchgate.net/publication/3481 83685_Bringing_the_Environment_Back_In_Overcoming_the_Tragedy_of_the_Diffusion_of_the_Commons_Metaphor (accessed on 5 June 2021).

57. Bryson, G. The Emergence of the Social Sciences from Moral Philosophy. Int. J. Ethics 1932, 42, 304-323. [CrossRef]

58. Kitzmueller, M.; Shimshack, J.P. Economic Perspectives on Corporate Social Responsibility. J. Econ. Lit. 2012, 50, 51-84. [CrossRef]

59. Aguinis, H.; Glavas, A. What We Know and Don't Know about Corporate Social Responsibility: A Review and Research Agenda. J. Manag. 2012, 38, 932-968. [CrossRef]

60. Campbell, J.L. Why would corporations behave in socially responsible ways? An institutional theory of corporate social responsibility. Acad. Manag. Rev. 2007, 32, 946-967. [CrossRef]

61. Porter, M.E.; Kramer, M.R. Creating Shared Value. Harv. Bus. Rev. 2011, 89, 62-77.

62. Mackey, J.; Sisodia, R. Conscious Capitalism: Liberating the Heroic Spirit of Business, Paperback ed.; Harvard Business Review Press: Boston, MA, USA, 2014; ISBN 978-1-62527-175-4.

63. Reid, A.J.; Eckert, L.E.; Lane, J.; Young, N.; Hinch, S.G.; Darimont, C.T.; Cooke, S.J.; Ban, N.C.; Marshall, A. “Two-Eyed Seeing": An Indigenous framework to transform fisheries research and management. Fish Fish. 2021, 22, 243-261. [CrossRef]

64. Khan, F.R.; Westwood, R.I.; Boje, D.M. 'I feel like a foreign agent': NGOs and corporate social responsibility interventions into Third World child labor. Hum. Relat. 2010, 63, 1417-1438. [CrossRef]

65. Jamali, D.; Karam, C.; Yin, J.; Soundararajan, V. CSR logics in developing countries: Translation, adaptation and stalled development. J. World Bus. 2017, 52, 343-359. [CrossRef]

66. Barranquero, A. Comunicacion Participativa y Dominios Del Buen Vivir Una Aproximacion Conceptual. In Proceedings of the Actas IV: Comunicación, Control y Resistencias, Tenerife, Spain, 4 December 2012; Volume IV, p. 203.

67. Chatterji, A.; Levine, D. Breaking down the Wall of Codes: Evaluating Non-Financial Performance Measurement. Calif. Manag. Rev. 2006, 48, 29-51. [CrossRef]

68. Wood, D.J. Measuring Corporate Social Performance: A Review. Int. J. Manag. Rev. 2010, 12, 50-84. [CrossRef]

69. Hickel, J.; Kallis, G. Is Green Growth Possible? New Polit. Econ. 2020, 25, 469-486. [CrossRef]

70. Bapuji, H.; Husted, B.W.; Lu, J.; Mir, R. Value Creation, Appropriation, and Distribution: How Firms Contribute to Societal Economic Inequality. Bus. Soc. 2018, 57, 983-1009. [CrossRef]

71. Utting, P. CSR and Equality. Third World Q. 2007, 28, 697-712. [CrossRef]

72. Kothari, A.; Demaria, F.; Acosta, A. Buen Vivir, Degrowth and Ecological Swaraj: Alternatives to sustainable development and the Green Economy. Development 2014, 57, 362-375. [CrossRef]

73. Moreno Sandoval, C.D. Critical Ancestral Computing: A Culturally Relevant Computer Science Education. PsychNol. J. 2013, 11, 91-112.

74. Colbourne, R.; Moroz, P.; Hall, C.; Lendsay, K.; Anderson, R.B. Indigenous works and two eyed seeing: Mapping the case for indigenous-led research. Qual. Res. Organ. Manag. Int. J. 2019, 15, 68-86. [CrossRef]

75. Gorge, H.; Herbert, M.; Özçağlar-Toulouse, N.; Robert, I. What Do We Really Need? Questioning Consumption through Sufficiency. J. Macromarket. 2015, 35, 11-22. [CrossRef]

76. Long, B.S. CSR and reconciliation with Indigenous peoples in Canada. Crit. Perspect. Int. Bus. 2019. [CrossRef]

77. Princen, T. The shading and distancing of commerce: When internalization is not enough. Ecol. Econ. 1997, 20, 235-253. [CrossRef]

78. Nurunnabi, M.; Esquer, J.; Munguia, N.; Zepeda, D.; Perez, R.; Velazquez, L. Reaching the sustainable development goals 2030: Energy efficiency as an approach to corporate social responsibility (CSR). GeoJournal 2020, 85, 363-374. [CrossRef]

79. Streimikiene, D.; Simanaviciene, Z.; Kovaliov, R. Corporate social responsibility for implementation of sustainable energy development in Baltic States. Renew. Sustain. Energy Rev. 2009, 13, 813-824. [CrossRef]

80. Ramirez, J. Impacts of neoliberal wind energy investments on environmental justice and human rights in Mexico. In Business and Development Studies: Issues and Perspectives; Routledge Taylor \& Francis Group: London, UK; New York, NY, USA, 2020; pp. 353-377, ISBN 978-1-138-05987-0.

81. Salazar Zarco, A.L. El tequio y sus formas comunales como clave política en la educación superior intercultural en México. La experiencia del ISIA en la región del bajo mixe en Oaxaca. In Educación Crítica y Emancipación; CLACSO: Buenos Aires, Argentina, 2018; pp. 9-29.

82. Colín, E.T. Tequio (Community work). In Indigenous Education through Dance and Ceremony; Palgrave Macmillan: London, UK, 2014; pp. 45-46.

83. McWilliams, A.; Siegel, D. Creating and Capturing Value: Strategic Corporate Social Responsibility, Resource-Based Theory, and Sustainable Competitive Advantage. J. Manag. 2011, 37, 1480-1495. [CrossRef] 
84. Peredo, A.M.; Chrisman, J.J. Toward a Theory of Community-Based Enterprise. Acad. Manag. Rev. 2006, 31, 309-328. [CrossRef]

85. Dietz, T.; Ostrom, E.; Stern, P.C. The Struggle to Govern the Commons. Science 2003, 302, 1907-1912. [CrossRef]

86. Carroll, A.B. The Four Faces of Corporate Citizenship. Bus. Soc. Rev. 1998, 100-101, 1-7. [CrossRef]

87. Matten, D.; Crane, A. Corporate Citizenship: Toward an Extended Theoretical Conceptualization. Acad. Manag. Rev. 2005, 30, 166-179. [CrossRef]

88. Barkin, D. Popular sustainable development, or ecological economics from below. In The Essential Guide to Critical Development Studies; Routledge: London, UK, 2017; p. 10.

89. Rodhouse, T.; Vanclay, F. Is free, prior and informed consent a form of corporate social responsibility? J. Clean. Prod. 2016, 131, 785-794. [CrossRef]

90. Cisneros, G.T. Indigenous Peoples and Mexico's Contributions to the 2030 Agenda. In Mexico and the Post-2015 Development Agenda; Villanueva Ulfgard, R., Ed.; Palgrave Macmillan US: New York, NY, USA, 2017; pp. 217-239. ISBN 978-1-137-59141-8.

91. Broad, R.; Fischer-Mackey, J. From extractivism towards buen vivir: Mining policy as an indicator of a new development paradigm prioritising the environment. Third World Q. 2017, 38, 1327-1349. [CrossRef]

92. Yaffe, N. Indigenous Consent: A Self-Determination Perspective. SSRN Electron. J. 2018. [CrossRef]

93. Elkington, J. Cannibals with Forks. The Triple Bottom Line of 21st Century; Capstone Publishing: Oxford, UK, 1997; ISBN 978-1900961-27-1.

94. Poole, A.K. Where is Goal 18? The Need for Biocultural Heritage in the Sustainable Development Goals. Environ. Values 2018, 27, 55-80. [CrossRef]

95. Lim, A.; Tsutsui, K. Globalization and Commitment in Corporate Social Responsibility: Cross-National Analyses of Institutional and Political-Economy Effects. Am. Sociol. Rev. 2012, 77, 69-98. [CrossRef]

96. Michelon, G.; Rodrigue, M.; Trevisan, E. The marketization of a social movement: Activists, shareholders and CSR disclosure. Account. Organ. Soc. 2020, 80, 101074. [CrossRef] 